INDEPENDENT JOURNAL OF MANAGEMENT \& PRODUCTION (IJM\&P)

http://www.ijmp.jor.br

v. 11, n. 6, September - October 2020

ISSN: 2236-269X

DOI: 10.14807/ijmp.v11i6.1152

\title{
THE EFFECTS OF ELECTRONIC WORD OF MOUTH (EWOM) ON THE ADOPTION OF CONSUMER EWOM INFORMATION
}

\author{
Phuong Viet Le-Hoang \\ Ho Chi Minh City Open University, Vietnam \\ E-mail: lehoangvietphuong@gmail.com
}

Submission: 10/23/2019

Revision: 11/6/2019

Accept: 11/22/2019

\section{ABSTRACT}

The purpose of this research is to explore and test the effect of electronic Wordof-mouth (eWOM) on the adoption of consumer eWOM information. Through the credibility variables of the eWOM, namely the trust of the eWOM news source, the quantity of eWOM, the quality of eWOM and consumer expertise in the case of female consumers when buying cosmetics in Ho Chi Minh City, Vietnam. To achieve this goal, the author does conduct research by submitting an online survey questionnaire and obtained 200 valid questionnaires. The online questionnaire has targeted internet users, who have previously purchased online and read reviews online received from the provider's website. The result from Exploratory Factor Analysis (EFA) shows that consumer expertise has the most significant effect on consumer adoption of eWOM information while the number of eWOM has the least impact. Besides, the credibility of eWOM news sources and the quality of eWOM also indirectly affect the adoption of eWOM information. What is more, the study suggests some recommendations to cosmetic businesses so that they develop applications or websites where assessments and quality of information are relevant, and the current expertise of consumers is increasingly present.

Keywords: eWOM; the trust of eWOM; the quantity of eWOM; the quality of eWOM; consumer expertise; adoption of eWOM informatio 
DOI: 10.14807/ijmp.v11i6.1152

\section{INTRODUCTION}

In the booming era of information technology as at present, there are many mass media developed; among them the most significant development is the internet. The internet is the most convenient tool for transferring a large amount of information at a fast rate to millions of people around the world; it impacts every aspect, every area of life. The internet not only helps people to expand their relationships and exchange of information and personal experiences, through which people can express their opinions and be creative in many areas.

With the steady development of the internet, consumers are increasingly using the advantages of the online environment to find information about integrated products and services in their purchasing decisions (ZHU; ZHANG, 2010; KING et al., 2014; TENG et al., 2014) via electronic Word-Of-Mouth. Recent research shows that the internet allows customers to use online platforms to share reviews with other users (HENNIG-THURAU et al., 2004; KIM; PARK, 2013).

Consumers quickly access and monitor the opinions, assessments, and feelings of other individuals to compare, choose, and make decisions for their needs, maximizing consumer rights... At the same time, they can also let their assessment stay, contributing their own experience to the following consumers. Word of mouth Electronic (eWOM) has long been evaluated as a powerful marketing tool (BICKART; SCHINDLER, 2001; KUMAR; BENBASAT, 2006; ZHANG et al., 2010).

Cheung and Thadani (2012) said that the internet had provided some very suitable platforms for eWOM forms such as blogs, forums, review websites, and shopping websites. Some previous studies have shown the impact of eWOM from the above foundation for the adoption of consumer eWOM information (BICKART; SCHINDLER, 2001; PARK et al., 2007; SEE-TO; HO, 2014). Therefore, this has created a diverse electronic word of mouth.

Standing in such a market, if consumers want to buy a quality product that suits their needs, they must thoroughly understand product information from different sources, if the information is attractive enough to They can accept it and then make a purchase decision. Consumers often search for information of cosmetics from relatives and friends, from a direct consultant at the point of sale, search through forums or social networking sites that are currently influential.

In particular, the form of searching for information via the Internet is now becoming more and more popular. Also, consumers tend to be more proactive in sharing commercial 
DOI: 10.14807/ijmp.v11i6.1152

information and rely on the information given by other consumers rather than information sold by the seller. Before consumers accept eWOM information when choosing cosmetics, they tend to imitate (especially women's psychology) each other through word of mouth.

The acceptance of eWOM information when choosing women's cosmetics depends mainly on negative or positive emotions coming from the manufacturer or business or the surrounding people. Women often like to share their feelings, experiences, and evaluations of a used product. From that fact, grasping the current trend of women's consumption, learning about the impact of eWOM on the adoption of eWOM information can help managers and businesses in bringing products to consumers more efficiently.

Therefore, the author conducts the research "The effects of electronic word of mouth (eWOM) on the adoption of consumer eWOM information." And this study applies the case for consumers who are women when buying cosmetics at Ho Chi Minh City.

\section{LITERATURE REVIEW AND HYPOTHESES DEVELOPMENT}

Adoption of information is a psychological action that affects consumers online through social norms or reviews/comments in the online environment (FAN; MIAO, 2012).

Previous studies have asked the following question: "How can an individual be affected in the process of receiving/applying ideas or information" (AJZEN, 1991; DAVIS, 1989). Sussman and Siegal (2003) studied this topic further to consider eWOM in a dual theoretical model named Information Acceptance Model (IAM) that individuals can be affected by a message in two directions: Center (central) and peripheral (SUSSMAN; SIEGAL, 2003). The central direction addresses the core contents of the message, while the peripheral direction addresses indirect issues related to the content of the message (CHEUNG et al., 2008).

IAM includes four research variables: Quality of the message (representing the central approach), the credible source (representing the peripheral approach), the usefulness of the information and the application of information believe. IAM is highly regarded by many scholars when applied to studies of eWOM (CHEUNG et al., 2008; SHU; SCOTT, 2014). This study also focuses on the eWOM theme, so the use of the IAM model is also considered appropriate. The elements of IAM applied in this study are the quality of the message, the credibility of the source. The author believes that, in order to accept a piece of particular information, recipients must first evaluate how useful it is to receive that information.

When an individual is willing to be aware and able to understand the arguments and words in the message, the quality of the argument will determine the level of influence of the 
DOI: 10.14807/ijmp.v11i6.1152

information. And when an individual has no motivation or inability to understand the arguments in the message, other out-of-flow suggestions will determine the level of influence of information (PETTY; CACIOPPO, 1986).

Trust of eWOM sources: Wathen and Burkell (2002) pointed out that the credibility of information resources is a crucial factor in supporting consumers to assess online information. The first task for consumers online is to evaluate the vehicle's credibility, based on its surface characteristics. If a website presents a credible, well-designed, and compelling image interface, it will attract consumers to stay on the site and continue using it.

The second task relates to the ranking of resources related to mail content since the credibility of the source is entirely consistent with credibility and expertise. The third task of the process involves assessing the interaction of presenting messages and content with consumers' cognitive state, which is determined from the consumer's experience. In an online environment, consumers rarely touch products directly or identify senders of EWOM. The credibility of the source is an essential predictor in the early stages when consumers are searching for and choosing a website, and it contributes to the credibility of the messages on the site (DABHOLKAR, 2006; DOU et al., 2012; HUSSAIN et al., 2017).

The credibility of the source for EWOM is defined as the degree to which it is perceived as credible or practical (CHEUNG et al., 2009). Awad and Rogowsky (2008) argue that trustworthiness of information resources is a leading determinant in consumer adoption of eWOM information and reducing uncertainty in both social and business interactions. Besides, Luo el at (2014) proved to be that the source credibility has a positive effect on perceived information credibility. Therefore, the author has the hypothesis $\mathrm{H} 1$ as follows:

- H1: The higher the eWOM information credibility, the higher the adoption of eWOM information from consumers.

Quantity of eWOM: The number of eWOM is defined as the number of reviews or comments on a product on all websites (FAN et al., 2013). When a consumer seeks online reviews, the number of eWOM makes opinions more diverse (CHEUNG; THADANI, 2010). The number of eWOM represents the popularity of a product. Reading many reviews by others can reduce consumer anxiety when deciding to buy because consumers believe that many others have also bought these products (CHATTERJEE, 2001). Park et al. (2007) provide evidence that the number of eWOM positively affects consumer adoption of eWOM information. Therefore, the author has hypothesis $\mathrm{H} 2$ as follows: 
DOI: 10.14807/ijmp.v11i6.1152

- H2: The higher the number of eWOM, the higher the adoption of consumer eWOM information.

Quality of eWOM: The quality of eWOM that consumers perceive is defined as the degree to which they feel about an offer or assessment that is effective, credible, accurate, or valid (CHEUNG et al., 2009). The quality of eWOM is the convincing power of discussions (BHATTACHERJEE; SANFORD, 2006), and it can measure the information characteristics such as relevance, timeliness, accuracy, and comprehensiveness (CHEUNG; THADANI, 2010).

Given the often anonymous nature of comments online, people tend not to trust the random review easily if there is not enough necessary information (RATCHFORD, 2001). The quality of eWOM is a critical element that is often discussed with the number of eWOM. When eWOM on the website wins consumer attention, consumers consider whether these reviews are worth reading. Information quality has long been proven as a significant predictor of the success of an information system (DELONE; MCLEAN, 1992).

Consumers are concerned about the correctness and usefulness of eWOM, and the quality of good content increases their readiness to trust eWOM (AWAD; ROGOWSKY, 2008). Park et al. (2007) and Cheung et al. (2009) pointed out that the high quality and the number of eWOM increase the adoption of consumer eWOM information. Therefore, the author has the hypothesis H3 as follows:

- H3: The higher the eWOM quality, the higher the adoption of consumer eWOM information.

Consumer expertise: Bickart and Schindler (2001) found that highly qualified consumers can quickly and accurately evaluate their knowledge and experience of an expensive product, this makes for sources of information that are seeking to increase by consumers who are not familiar with products/services. According to Petty et al. (1983), consumer expertise is related to the ability to process information. Park and Kim (2008) found that highly qualified customers can evaluate information by experience and knowledge. Similarly, Bansal and Boyer (2000) indicates that higher-skilled consumers will accept eWOM information more efficiently and have less consultation with others. Also, Ismagilova et al. (2019) found that source expertise affects information adoption. Therefore, the author has the hypothesis $\mathrm{H} 4$ as follows:

- H4: The higher the consumer expertise, the higher the adoption of consumer eWOM information. 
DOI: 10.14807/ijmp.v11i6.1152

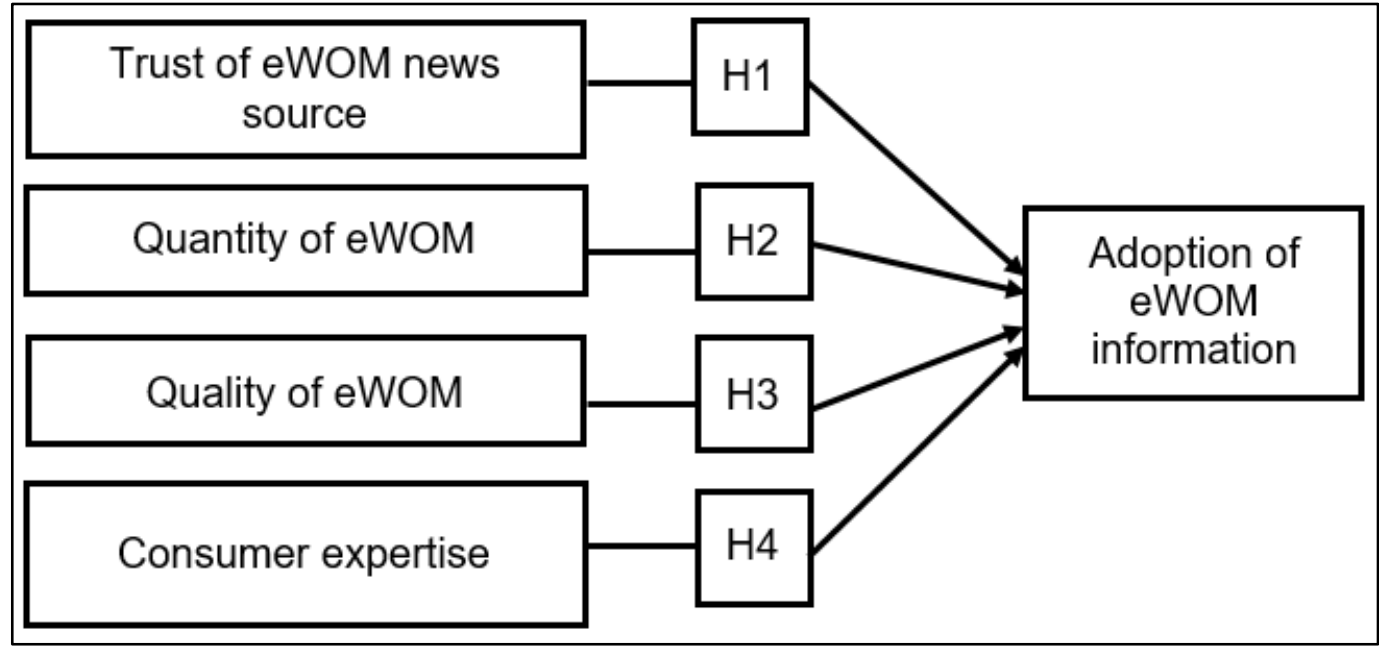

Figure 1: Proposed research model of the author.

\section{METHODOLOGY}

The author uses mix method including qualitative research method to explore the scale and quantitative research methods to analyze the impact of electronic word of mouth on the adoption of eWOM information: Case For consumers who are women when buying cosmetics in Ho Chi Minh City, Vietnam.

This research uses the qualitative research method via group discussions and expert discussions to build research models, scales, questionnaires, and preliminary surveys to complete research models before issuing the questionnaire. This study was conducted through the consultation of five-person experts and a qualitative survey of 20 consumers who bought goods in convenience stores to produce a complete research model and scale, consistent unify.

The quantitative research method is based on the fact that the author conducts a survey to filter out a list of subjects that match the research objectives. Because Ho Chi Minh City is the largest city in Vietnam in terms of population and economy, it ranks second in area and is also one of Vietnam's most important economic, cultural and educational centers. Therefore, the scope of the author's study only investigates those who are living in Ho Chi Minh City. The survey method is structured with a questionnaire to collect descriptive information about the status of customers who have been using cosmetics, measuring the impact of eWOM on the adoption of current eWOM information of consumers.

Questions are designed according to the Likert scale (5 levels) from 1 to 5 according to the degree of increasing with (1) strongly disagree, (2) disagree, (3) neutral, (4) agree, and (5) strongly agree. According to Hair et al. (2006), the sample size can be determined according to the ratio of observed / variable measurements of 5: 1 (5 observations for one variable). 
DOI: 10.14807/ijmp.v11i6.1152

Besides, the online survey has three filter questions from the beginning of questionnaires to make sure that the research can reach the target respondent. The first question is "What is your gender?” and the answer is “man” or “woman.” If the respondent answers man, he has to stop fill the online survey. If the respondent answers the woman, she will answer the second filter question.

The second filter question is that "Do you live in Ho Chi Minh city or not?". If the woman says no, she stops the online survey immediately. If the woman says yes, she can continue to do the online survey. The last filter question is that "in the last six months, do you buy any cosmetics?”. If the woman says no, she stops the online survey. If the woman says yes, she continues to fill the online survey. And the study split three parts: Part one is the information, and that includes age, occupation, income.

Part two is a cosmetic survey, and it has four questions, namely (1) In the last six months, have you purchased any cosmetic products from any of the following brands? (2) Which source can you find out the information about cosmetic products? (3) What is your average daily Internet access time? (4) How do you usually receive information about cosmetics via the Internet? Finally, Part three is main survey, and the questions in this part measure electronic Word-of-mouth (23 questions) on the adoption of consumer eWOM information (three questions).

In this study, there are variables so the minimum sample size can be calculated as $\mathrm{n}=5 \times 26=130$. Although the minimum sample size needs only 130 surveys, the author decided to send and 250 questionnaires. In quantitative research, the author uses descriptive statistical methods, assessed for reliability through Cronbach's Alpha coefficients, EFA method, and regression to determine factors of electronic word of mouth impact the adoption of eWOM information.

\section{ANALYSIS AND RESULTS}

\subsection{Data description:}

After the two months to conduct the survey from June to July in 2019 and do data analysis in the first two weeks of August, the author sends 250 questionnaires, collected 215 questionnaires and choose 200 valid respondents to analyze, and the following table can describe the data: 
DOI: 10.14807/ijmp.v11i6.1152

Table 1: Data description

\begin{tabular}{|c|c|c|c|}
\hline \multicolumn{1}{|c|}{ Age } & Under 18 years old & Frequency & Percent \\
\hline & From 18 - under 35 years old & 12 & $\mathbf{6 . 0}$ \\
\cline { 2 - 4 } & From 35 - 50 years old & 106 & $\mathbf{5 3 . 0}$ \\
\cline { 2 - 4 } & Over 50 years old & 67 & $\mathbf{3 3 . 5}$ \\
\cline { 2 - 4 } & Student & 15 & $\mathbf{7 . 5}$ \\
\hline \multirow{4}{*}{ Job } & Officer & 38 & $\mathbf{1 9 . 0}$ \\
\cline { 2 - 4 } & Business & 88 & $\mathbf{4 4 . 0}$ \\
\cline { 2 - 4 } & Housewife & 51 & $\mathbf{2 5 . 5}$ \\
\cline { 2 - 4 } & Other & 18 & $\mathbf{9 . 0}$ \\
\cline { 2 - 4 } & Under 5 million VND & 5 & $\mathbf{2 . 5}$ \\
\hline \multirow{3}{*}{ Income } & From 5 - under 10 million VND & 58 & $\mathbf{2 9 . 0}$ \\
\cline { 2 - 4 } & From 10 - 20 million VND & 103 & $\mathbf{5 1 . 5}$ \\
\cline { 2 - 4 } & Over 20 million VND & 36 & $\mathbf{1 8 . 0}$ \\
\cline { 2 - 4 } & & 3 & $\mathbf{1 . 5}$ \\
\hline
\end{tabular}

Age: With age statistics as shown below, among 200 respondents, people aged 18 to under 35 have the highest number of responses of 106, accounting for $53 \%$. The subjects aged 35 to 50 years old had 67 respondents, accounting for 33.5\%. Next is the age of over 50 years old with 15 respondents, accounting for 7.5\%. Moreover, the people under the age of 18 have the lowest number of 12 answers, accounting for $6 \%$. It shows that the respondents focus on groups of ages from 18 to under 35 years old.

Occupation: With the above income statistics, in the 200 respondents, the occupation of office workers has the highest number of respondents, 88 , accounting for $44 \%$. The business people have 51 respondents, accounting for $25.5 \%$. Students have 38 answers, accounting for 19\%. People with occupations are housewives with 18 respondents, accounting for $9 \%$ and the last ones with the lowest number of 5 respondents, accounting for $2.5 \%$. It shows that the respondents focus on the group of office workers.

Income level: With the income level as shown in the chart below, among the 200 respondents, those with incomes from 5 to under 10 million VND have the highest number of respondents of 103, accounting for a proportion 51.5\%. Those with incomes below VND 5 million VND have 58 respondents, accounting for 29\%. Next, 36 respondents had income from 10 to 20 million VND, accounting for $18 \%$. And finally, the income level below VND 20 million has the lowest number of 3 respondents, accounting for $1.5 \%$. It shows that the respondents focus on groups with incomes from 5 to less than 10 million VND.

The cosmetic brands bought in the last six months of consumers have nearly equal proportions, of which only The Face Shop brand has the highest rate with $19 \%$ and Shiseido brand has the lowest rate with $1.5 \%$. Shows that current consumers are very interested in using imported products. 
ISSN: 2236-269X

DOI: 10.14807/ijmp.v11i6.1152

When information on cosmetics is needed, consumers often use a variety of information channels, of which the most used information channel is the Internet with 58\% and the lowest is using the information on the catalog with $4.5 \%$.

The majority of consumers have access to the Internet in general, and the results are nearly equal, those with access from 2-3 hours have the highest rate with $30 \%$, and the lowest is above 5 hours with $17 \%$.

For the form of receiving information on cosmetics via the Internet, consumers are interested in electronic information on social networks is the highest, namely on Facebook with $58.5 \%$.

\subsection{Reliability test: Cronbach's Alpha}

According to the research results of Nunnally and Bernstein (1994), the criteria for accepting variables: (1) Variables with correlation variables - total (Corrected Item - Total Correlation) if less than 0.3 will be rejected. (2) Cronbach's Alpha coefficient of 0.6 or higher will be received.

Following the two conditions above, the analytical variables are considered acceptable and appropriate to analyze the next steps. Therefore, all remaining items satisfy the condition so this can be used for analyzing Exploratory Factor.

Table 2: Constructs, corrected item - total correlation and Cronbach Alpha

\begin{tabular}{|c|c|c|c|}
\hline Items & Constructs & $\begin{array}{l}\text { Corrected Item- } \\
\text { Total Correlation }\end{array}$ & $\begin{array}{l}\text { Cronbach's Alpha } \\
\text { if Item Deleted }\end{array}$ \\
\hline \multicolumn{4}{|c|}{ Trust of eWOM news source } \\
\hline TRUST1 & $\begin{array}{l}\text { I believe in information provided by close } \\
\text { or familiar people }\end{array}$ & 0.663 & 0.827 \\
\hline TRUST2 & I think the sender of information is credible & 0.650 & 0.829 \\
\hline TRUST3 & $\begin{array}{l}\text { I think that senders have experienced product } \\
\text { consumption }\end{array}$ & 0.585 & 0.838 \\
\hline TRUST4 & $\begin{array}{l}\text { I look for information on websites that have } \\
\text { a nice, eye-catching interface }\end{array}$ & 0.646 & 0.830 \\
\hline TRUST5 & $\begin{array}{l}\text { I believe that the information on the website } \\
\text { is clearly visible and easy to find }\end{array}$ & 0.575 & 0.840 \\
\hline TRUST6 & $\begin{array}{l}\text { I searched for information on the popular } \\
\text { website }\end{array}$ & 0.561 & 0.842 \\
\hline TRUST7 & $\begin{array}{l}\text { I was attracted to the information of people } \\
\text { with similar tastes, habits and consumer } \\
\text { experiences }\end{array}$ & 0.638 & 0.831 \\
\hline \multicolumn{4}{|c|}{ Cronbach's Alpha $=0.854$} \\
\hline \multicolumn{4}{|c|}{ Quality of eWOM } \\
\hline QUAL1 & $\begin{array}{l}\text { The information I received or found is } \\
\text { credible }\end{array}$ & 0.715 & 0.837 \\
\hline QUAL2 & $\begin{array}{l}\text { The information I received or found } \\
\text { provided the correct things }\end{array}$ & 0.659 & 0.846 \\
\hline
\end{tabular}


INDEPENDENT JOURNAL OF MANAGEMENT \& PRODUCTION (IJM\&P)

http://www.ijmp.jor.br

v. 11, n. 6, September - October 2020

ISSN: 2236-269X

DOI: 10.14807/ijmp.v11i6.1152

\begin{tabular}{|c|c|c|c|}
\hline QUAL3 & $\begin{array}{l}\text { The information I received or found is } \\
\text { clearly presented }\end{array}$ & 0.608 & 0.855 \\
\hline QUAL4 & $\begin{array}{l}\text { I think the information is objectively sent by } \\
\text { the sender }\end{array}$ & 0.667 & 0.845 \\
\hline QUAL5 & $\begin{array}{l}\text { I think the information is provided from the } \\
\text { true experience of the sender when they are } \\
\text { or are using cosmetics }\end{array}$ & 0.670 & 0.844 \\
\hline QUAL6 & $\begin{array}{l}\text { I think the information is given with good } \\
\text { purpose to share the experience of cosmetics } \\
\text { with other consumers }\end{array}$ & 0.672 & 0.844 \\
\hline \multicolumn{4}{|c|}{ Cronbach's Alpha $=0.868$} \\
\hline \multicolumn{4}{|c|}{ Quantity of eWOM } \\
\hline QUAN1 & $\begin{array}{l}\text { In the same site, the larger the number of } \\
\text { reviews for a product, the more credible the } \\
\text { information is. }\end{array}$ & 0.606 & 0.670 \\
\hline QUAN2 & $\begin{array}{l}\text { I believe in reviews that attract many people } \\
\text { to comment. }\end{array}$ & 0.603 & 0.674 \\
\hline QUAN3 & $\begin{array}{l}\text { Products are evaluated on many different } \\
\text { websites, the information about that product } \\
\text { is more credible. }\end{array}$ & 0.578 & 0.702 \\
\hline \multicolumn{4}{|c|}{ Cronbach's Alpha = 0.763} \\
\hline \multicolumn{4}{|c|}{ Consumer expertise } \\
\hline EXP1 & I have a lot of knowledge about cosmetics & 0.675 & 0.853 \\
\hline EXP2 & I have a lot of experience using cosmetics & 0.680 & 0.852 \\
\hline EXP3 & $\begin{array}{l}\text { I have a lot of experience finding } \\
\text { information online }\end{array}$ & 0.578 & 0.865 \\
\hline EXP4 & I know many reputable cosmetic websites & 0.698 & 0.850 \\
\hline EXP5 & I know many websites that are well known & 0.658 & 0.855 \\
\hline EXP6 & I have the ability to select useful information & 0.624 & 0.860 \\
\hline EXP7 & $\begin{array}{l}\text { I make the decision to buy mainly based on } \\
\text { my own understanding rather than through } \\
\text { the information given by other consumers }\end{array}$ & 0.659 & 0.855 \\
\hline \multicolumn{4}{|c|}{ Cronbach's Alpha $=0.874$} \\
\hline \multicolumn{4}{|c|}{ Adoption of eWOM } \\
\hline ADOP1 & $\begin{array}{l}\text { The eWOM information provides me with } \\
\text { the knowledge / perspective on cosmetic } \\
\text { consumption }\end{array}$ & 0.732 & 0.760 \\
\hline ADOP2 & $\begin{array}{l}\text { EWOM information makes it easy for me to } \\
\text { make the decision to buy cosmetics (Buy or } \\
\text { not buy) }\end{array}$ & 0.761 & 0.735 \\
\hline ADOP3 & $\begin{array}{l}\text { EWOM information has improved efficiency } \\
\text { in making the choice of cosmetic brands } \\
\text { suitable for me }\end{array}$ & 0.641 & 0.850 \\
\hline
\end{tabular}

\subsection{Exploratory Factor Analysis (EFA)}

Exploratory Factor Analysis (EFA) is an analytical technique which is aimed to reduce data, so it is beneficial for identifying variables by the group. In the exploratory factor analysis, the author used Principal Component Analysis and Varimax rotation to group the components.

\subsubsection{Independent variables}

The results show that $\mathrm{KMO}$ is 0.892 and can make sure the requirement $0.5<\mathrm{KMO}<1$. Bartlett is 2079.701 with sig $=0.00<0.05$, so all of the variables are correlation together in each 
DOI: 10.14807/ijmp.v11i6.1152

component. Total variance explained equals $59.341 \%$, and it is greater than $50 \%$; as a result, it can meet the requirement of variance explained. From this one, this research can conclude that variables can explain $60.664 \%$ in changing factors. Also, eigenvalues equal $1.484>1$, and it is the fluctuation that can explain for each factor, so the extracted factors have a significant summarize in the best way. The rotated matrix in EFA show that the loading factor is higher than 0.5 , and it can divide into six components by the following table:

Table 3: Rotated matrix

\begin{tabular}{|c|c|c|c|c|c|}
\hline \multirow[t]{2}{*}{ Concepts } & \multirow[t]{2}{*}{ Items } & \multicolumn{4}{|c|}{ Component } \\
\hline & & 1 & 2 & 3 & 4 \\
\hline \multirow[t]{7}{*}{ Consumer expertise } & EXP4 & 0.772 & & & \\
\hline & EXP1 & 0.743 & & & \\
\hline & EXP7 & 0.714 & & & \\
\hline & EXP5 & 0.693 & & & \\
\hline & EXP2 & 0.676 & & & \\
\hline & EXP6 & 0.639 & & & \\
\hline & EXP3 & 0.632 & & & \\
\hline \multirow{7}{*}{$\begin{array}{c}\text { Trust of eWOM } \\
\text { news source }\end{array}$} & TRUST2 & & 0.763 & & \\
\hline & TRUST4 & & 0.737 & & \\
\hline & TRUST7 & & 0.727 & & \\
\hline & TRUST1 & & 0.697 & & \\
\hline & TRUST3 & & 0.691 & & \\
\hline & TRUST6 & & 0.585 & & \\
\hline & TRUST5 & & 0.580 & & \\
\hline \multirow[t]{6}{*}{ Quantity of eWOM } & QUAL2 & & & 0.755 & \\
\hline & QUAL1 & & & 0.753 & \\
\hline & QUAL4 & & & 0.753 & \\
\hline & QUAL6 & & & 0.734 & \\
\hline & QUAL5 & & & 0.729 & \\
\hline & QUAL3 & & & 0.709 & \\
\hline \multirow[t]{3}{*}{ Quality of eWOM } & QUAN3 & & & & 0.829 \\
\hline & QUAN1 & & & & 0.811 \\
\hline & QUAN2 & & & & 0.713 \\
\hline \multicolumn{2}{|c|}{ KMO } & \multicolumn{4}{|c|}{0.892 (sig. $=0.000)$} \\
\hline \multicolumn{2}{|c|}{\begin{tabular}{|c|} 
Eigenvalues \\
\end{tabular}} & \multicolumn{4}{|c|}{1.484} \\
\hline \multicolumn{2}{|c|}{ Total Variance Explained } & \multicolumn{4}{|c|}{59.341} \\
\hline
\end{tabular}

\subsubsection{Dependent variable:}

The results show that $\mathrm{KMO}$ is 0.706 and can make sure the requirement $0.5<\mathrm{KMO}<1$. Bartlett is 262.116 with sig $=0.00<0.05$, so all of the variables are correlation together in each component. Total variance explained equals $76.484 \%$, and it is greater than $50 \%$; as a result, it can meet the requirement of variance explained. From this one, this research can conclude that variables can explain $76.484 \%$ in changing factors.

Also, eigenvalues equal $2.295>1$, and it is the fluctuation that can explain for each factor, so the extracted factors have a significant summarize in the best way. The rotated matrix 
INDEPENDENT JOURNAL OF MANAGEMENT \& PRODUCTION (IJM\&P)

http://www.ijmp.jor.br

v. 11, n. 6, September - October 2020

ISSN: 2236-269X

DOI: 10.14807/ijmp.v11i6.1152

in EFA show that the loading factor is higher than 0.5 and it can divide into six components by the following table:

Table 4: Dependent variable, and testing

\begin{tabular}{|c|c|c|}
\hline \multicolumn{2}{|c|}{ Dependent variable } & Component \\
\hline \multirow{3}{*}{ Adoption of eWOM } & ADOP & $\mathbf{0 . 9 0 3}$ \\
\cline { 2 - 3 } & ADOP & $\mathbf{0 . 8 8 9}$ \\
\cline { 2 - 3 } & ADOP & $\mathbf{0 . 8 2 9}$ \\
\hline KMO & $\mathbf{0 . 7 0 6}$ (sig. $=\mathbf{0 . 0 0 0}$ ) \\
\hline Eigenvalues & $\mathbf{2 . 2 9 5}$ \\
\hline Total Variance Explained & $\mathbf{7 6 . 4 8 4}$ \\
\hline
\end{tabular}

\subsection{Regression}

Regression analysis finds where elements of electronic word of mouth impact the adoption of eWOM information and measure the impact of these factors.

Meanwhile, ADOP is a dependent variable and it can measure of electronic word of mouth impact the adoption of eWOM information: Case For consumers who are women when buying cosmetics in Ho Chi Minh City, Vietnam, and EXP, TRUST, QUAL, QUAN are independent variables that can measure consumer expertise, trust of eWOM news source, quantity of eWOM, quality of eWOM.

Table 5: Regression results

\begin{tabular}{|c|c|c|c|c|c|c|c|}
\hline \multirow[b]{2}{*}{ Model } & \multicolumn{2}{|c|}{$\begin{array}{l}\text { Unstandardized } \\
\text { Coefficients }\end{array}$} & \multirow{2}{*}{$\begin{array}{l}\text { Standardized } \\
\text { Coefficients } \\
\text { Beta } \\
\end{array}$} & \multirow[b]{2}{*}{$\mathbf{t}$} & \multirow[b]{2}{*}{ Sig. } & \multicolumn{2}{|c|}{ Collinearity } \\
\hline & Beta & Sd. Error & & & & Tolerance & VIF \\
\hline (Constant) & -1.188 & 0.273 & & -4.356 & 0.000 & & \\
\hline EXP & 0.561 & 0.068 & 0.449 & 8.252 & 0.000 & 0.572 & 1.750 \\
\hline TRUST & 0.247 & 0.067 & 0.184 & 3.678 & 0.000 & 0.672 & 1.487 \\
\hline QUAL & 0.353 & 0.058 & 0.291 & 6.030 & 0.000 & 0.727 & 1.375 \\
\hline QUAN & 0.135 & 0.050 & 0.122 & 2.689 & 0.008 & 0.817 & 1.225 \\
\hline \multicolumn{3}{|c|}{ Adjusted R ${ }^{2}$} & \multicolumn{5}{|c|}{0.663} \\
\hline \multicolumn{3}{|c|}{ Sig. } & \multicolumn{5}{|c|}{0.000} \\
\hline \multicolumn{3}{|c|}{ Durbin Watson } & \multicolumn{5}{|c|}{2.143} \\
\hline
\end{tabular}

The table of significance test results shows the sig of the four professional factors of consumers, the credibility of the eWOM source, the quality of eWOM and the number of eWOM are less than 0.05 (respectively sig $=0.000$, sig $=0.000$, sig $=0.000$ and $\operatorname{sig}=0.008$ ). Therefore, all four factors are correlated with the adoption of eWOM information and adoption in the multivariate regression model, showing the correlation of 4 factors: consumer expertise, credibility of eWOM news sources, eWOM quality and eWOM numbers are accepted. Correlation regression model:

$$
\mathrm{ADOP}=0.449 * \mathrm{EXP}+0.291 * \mathrm{TRUST}+0.184 * \mathrm{QUAL}+0.122 * \mathrm{QUAN} .
$$


DOI: 10.14807/ijmp.v11i6.1152

The above regression equation shows that the factor "Consumer expertise" has the strongest impact because the beta coefficient of this factor is the highest (beta $=0.449$ ). The second most powerful factor is eWOM quality with beta $=0.291<0.449$. The third most powerful factor is the eWOM source credibility with beta $=0.184<0.291$. Finally, the factor eWOM quantity has the lowest impact with beta $=0.122$.

The correlation between the four factors affecting the adoption of eWOM is a positive relationship because the beta coefficient of the four factors is positive (beta>0). Besides, variance inflation factor (VIF) of the independent variables in the model is small. In particular, VIF of 4 professional factors of consumers, the credibility of eWOM source, eWOM quality and number of eWOM are 1.750, 1.487, 1.375 and 1.225 respectively, showing that the multivariate variables of the independent variables are negligible, and the independent variables in the model are acceptable (when VIF value exceeds 10 is a sign of multicollinearity phenomenon).

The relevance of the regression equation Model summary: Adjusted R Square $=0.663$ showing four factors namely consumers expertise, the credibility of eWOM news source, eWOM quality and the number of eWOM impacts do explain $66.3 \%$ the effect of eWOM information. The above regression model does not violate the hypothesis of the first sequence correlation phenomenon in the model because the Durbin-Watson test coefficient $=2.143$ belongs to the range from 1 to 3 .

In this case, we see that the sig value is small $=0.000<0.005$, indicating that the usage model is appropriate and that the variables meet the adoption criteria.

\subsection{Hypothesis testing:}

Table 6: Hypothesis and result

\begin{tabular}{|c|l|c|}
\hline Hypothesis & \multicolumn{1}{|c|}{ Content } & Result \\
\hline H1 & $\begin{array}{l}\text { The higher the eWOM information credibility, the higher the adoption } \\
\text { of eWOM information from consumers. }\end{array}$ & Accepted \\
\hline H2 & $\begin{array}{l}\text { The higher the number of eWOM, the higher the adoption of consumer } \\
\text { eWOM information. }\end{array}$ & Accepted \\
\hline H3 & $\begin{array}{l}\text { The higher the eWOM quality, the higher the adoption of consumer } \\
\text { eWOM information. }\end{array}$ & Accepted \\
\hline H4 & $\begin{array}{l}\text { The higher the consumer expertise, the higher the adoption of consumer } \\
\text { eWOM information. }\end{array}$ & Accepted \\
\hline
\end{tabular}

\section{CONCLUSION}

After quantitative research, based on hypothesis test results, the author has some specific recommendations to use eWOM as a marketing tool as follows: 
DOI: 10.14807/ijmp.v11i6.1152

Enhance the expertise of consumers by creating easy-to-use cosmetic lines that are easily accessible to consumers, thereby forming habits and experiences when re-using those cosmetic lines. At the same time, provide information about cosmetics so that they can be easily understood, absorbed, and saved in consumers' minds.

Businesses should create eye-catching websites, meaningful slogans to help consumers quickly identify website selling cosmetics. Along with good slogans, businesses should arrange items, product search boxes or news articles, images of a cosmetics so that they are easy to see, read and understand or assess, comments by consumers who bought before. Provide useful and accurate information about the use of cosmetics as well as appropriate products for consumers, thereby helping consumers easily select the information and products they feel the best.

Businesses also need to select the reviews, authentic and accurate comments of previous buyers so that other consumers can easily accept and thereby give their opinions.

Improve eWOM quality to improve consumer adoption of eWOM information. Enterprises need to create quality assurance information, including high credibility, personal information (no advertising), clear, easy to understand, and easy to find information. Information will be displayed clearly, easy to understand and attractive by selecting keywords that are easy to find for users to quickly reference, information to be refined for easy understanding and an extended stay in the minds of consumers. Create your website about products, and the website's activities must be active and regular, this website must be linked to forums regularly with advertising, promotion, and gratitude activities to remind customers about the product. Increase the credibility of information by selecting reputable and objective talk channels to spread the message. Discussion channels also need to target the right people; here are the channels where women are interested in beauty, health, and self-care.

Companies should create a website for their brand of cosmetics, linking to websites about women, fashion, ... beauty websites and social networks like Facebook to post information about the company's products regularly. Besides, it is necessary to create categories on beauty counseling, skin care, as well as a conversation about the effects of each type of cosmetics with consumers.

Companies should post much useful information to increase the site's usability and professionalism, which will increase consumer sympathy for the company's website and cosmetic brand. Companies also need to pay attention to the form and decoration of the website, so the website interface should be eye-catching, elegant, and informative. 
DOI: 10.14807/ijmp.v11i6.1152

The company can combine sending emails to familiar customers or members to join their website when there are new products or information about discounts and promotions and ask them to send that email to friends and others.

The more people mention their products, the more likely they are to succeed. Increasing the number of eWOM in the community makes it easier for customers to consult information and feel more secure in accepting information about cosmetic products. The company should create many topics to discuss products through forums, group meetings, fan page, ... the more topics the people have to comment and contribute, the more likely it will create customers' appeal. In order to do that, businesses must have the choice of favorite and multi-participant discussion channels, while offering exciting discussion topics, creating trust from the article to the people. Also, updating much information according to the current trend to attract consumers to make judgments and demands for their products.

Although some results have been achieved, the thesis still has the following limitations: First, the research results may be limited by localities because the analytical data is only surveyed in Ho Chi Minh City. Secondly, the sampling method is chosen as the non-probability sampling method and therefore, has natural limitations when it comes to generalizing data. Third, the sample size selected for the study is still small compared to the overall study, which may also adversely affect the credibility of research results.

Finally, there may be many factors affecting the adoption of consumer eWOM information that this study has not discussed, to explain more clearly the adoption of eWOM information. With the above limitation, it is expected that other author can make further research efforts in the future and solve the bad points that exist in this study to contribute to the joint development of the field — marketing areas, especially Internet marketing.

In the future, if there are conditions to develop this research, it is necessary to pay attention to the following issues: Increasing the sample size in the direction of increasing the survey sample rate compared to the overall. Include several other factors that are thought to have an impact on consumer adoption of eWOM information when purchasing cosmetics into the research model proposed during the study.

\section{REFERENCES}

AJZEN, I. (1991) The theory of planned behavior. Organizational behavior and human decision processes, v. 50, n. 2, p. 179-211.

AWAD, N. F.; ROGOWSKY, A. (2008) Establishing trust in electronic commerce though online word of mouth: An examination across genders. Journal of Management 
DOI: 10.14807/ijmp.v11i6.1152

Information Systems, v. 24, n. 4, p. 101-121.

BANSAL, H. S.; BOYER, P. A. (2000) Word-ofmouth processes within a services purchase decision context. Journal of service research, v. 3, p. 166-177.

BHATTACHERJEE, A.; SANFORD, C. (2006) Influence processes for information technology acceptance: An elaboration likelihood model. MIS Quarterly, v. 30, n. 4, p. 805835.

BICKART, B.; SCHINDLER, R. M. (2001) Internet forums as influential sources of consumer information. Journal of interactive marketing, v. 15, p. 31-40.

CHATTERJEE, P. (2001) Online Reviews - Do Consumers Use Them? Association for Consumer Research, v. 28, p. 129-134.

CHEUNG, C. M.; THADANI, D. R. (2010) The Effectiveness of Electronic Word-of-Mouth Communication: A Literature Analysis. In: Implications for the Individual, Enterprises and Society. Bled: Bled eConference eTrust, p.331-340.

CHEUNG, C. M.; THADANI, D. R. (2012) The impact of electronic word-of-mouth communication: A literature analysis and integrative model. Decision support systems, v. 54, n. 1, p. 461-470.

CHEUNG, C. M.; LEE, M. K.; RABJOHN, N. (2008) The impact of electronic word-ofmouth: The adoption of online opinions in online customer communities. Internet research, v. 18, n. 3, p. 229-247.

CHEUNG, M. Y.; LUO, C.; SIA, C. L.; CHEN, H. (2009) Credibility of electronic word-ofmouth: Informational and normative determinants of online consumer recommendations. International journal of electronic commerce, v. 4, p. 9-38.

DABHOLKAR, P. A. (2006) Factors influencing consumer choice of a "rating web site": An experimental investigation of an online interactive decision aid. Journal of Marketing Theory and Practice, v. 14, n. 4, p. 259-273.

DAVIS, F. D. (1989) Perceived usefulness, perceived ease of use, and user acceptance of information technology. MIS quarterly, v. 13, n. 3, p. 319-340.

DELONE, W. H.; MCLEAN, E. R. (1992) Information systems success: The quest for the dependent variable. Information Systems Research, v. 3, n. 4, p. 60-95.

DOU, X.; WALDEN, J. A.; LEE, S.; LEE, J. Y. (2012) Does source matter? Examining source effects in online product reviews. Computers in Human Behavior, v. 28, n. 5, p. 1555-1563.

FAN, Y. W.; MIAO, Y. F. (2012) Effect of electronic word-of-mouth on consumer purchase intention: The perspective of gender differences. International Journal of Electronic Business Management, v. 10, n. 3, p. 175-181.

FAN, Y. W.; MIAO, Y. F.; FANG, Y. H.; LIN, R. Y. (2013) Establishing the adoption of electronic word-of-mouth through consumers' perceived credibility. International Business Research, v. 6, n. 3, p. 58-65.

HAIR, J. F.; ANDERSON, R. E.; TATHAM, R. L.; BLACK, W. C. (2006) Multivariate data analysis. Prentice-Hall, International, Inc, 6.

HENNIG-THURAU, T.; GWINNER, K. P.; WALSH, G.; GREMLER, D. D. (2004)

Electronic word-of-mouth via consumer-opinion platforms: What motivates consumers to articulate themselves on the Internet? Journal of Interactive Marketing, v. 18, n. 1, p. 38- 
52.

HUSSAIN, S.; AHMED, W.; JAFAR, R. M. S.; RABNAWAZ, A.; JIANZHOU, Y. (2017) eWOM source credibility, perceived risk and food product customer's information adoption. Computers in Human Behavior, v. 66, p. 96-102.

ISMAGILOVA, E.; SLADE, E.; RANA, N. P.; DWIVEDI, Y. K. (2019) The effect of characteristics of source credibility on consumer behaviour: A meta-analysis. Journal of Retailing and Consumer Services.

KIM, S.; PARK, H. (2013) Effects of various characteristics of s-commerce on consumers' trust and trust performance. International Journal of Information Management, v. 33, n. 2, p. 318-332.

KING, R. A.; PRADEEP, R.; VICTORIA, D. B. (2014) What We Know and Don't Know About Online Word-of-Mouth: A Review and Synthesis of the Literature. Journal of Interactive Marketing, v. 28, n. 3, p. 167-183.

KUMAR, N.; BENBASAT, I. (2006) Research note: The influence of recommendations and consumer reviews on evaluations of websites. Information Systems Research, v. 17, n. 4, p. 425-439.

LUO, C.; WU, J.; SHI, Y.; XU, Y. (2014) The effects of individualism-collectivism cultural orientation on eWOM information. International Journal of Information Management, $\mathrm{v}$. 34, n. 4, p. 446-456.

NUNNALLY, J. C.; BERNSTEIN, I. H. (1994) The Assessment of Reliability.

Psychometric Theory, v. 3, n. 1, p. 248-292.

PARK, D. H.; KIM, S. (2008) The effects of consumer knowledge on message processing of electronic word-of-mouth via online consumer reviews. Electronic Commerce Research and Applications, v. 7, p. 399-410.

PARK, D. H.; LEE, J.; HAN, I. (2007) The effect of on-line consumer reviews on consumer purchasing intention: The moderating role of involvement. International journal of electronic commerce, v. 4, p. 125-148.

PETTY, R. E.; CACIOPPO, J. T. (1986) Communication and Persuasion: Central and Peripheral Routes to Attitude Change. New York: Springer-Verlag.

PETTY, R. E.; CACIOPPO, J. T.; SCHUMANN, D. (1983) Central and peripheral routes to advertising effectiveness: The moderating role of involvement. Journal of Consumer

Research, v. 10, n. 2, p. 135-146.

RATCHFORD, B.; TALUKDAR, D.; LEE, M. (2001) A model of consumer choice of the Internet as an information source. International Journal of Electronic Commerce, v. 5, n. 3, p. 7-22.

SEE-TO, E. W.; HO, K. K. (2014) Value cocreation and purchase intention in social network sites: The role of electronic Word-of-Mouth and trust-A theoretical analysis. Computers in Human Behavior, v. 31, p. 182-189.

SHU, M.; SCOTT, N. (2014). Influence of social media on Chinese students' choice of an overseas study destination: An information adoption model perspective. Journal of Travel and Tourism Marketing, v. 31, n. 2, p. 286-302.

SUSSMAN, S. W.; SIEGAL, W. S. (2003) Informational influence in organizations: An integrated approach to knowledge adoption. Information systems research, v. 14, n. 1, p. 47-65. 
TENG, S.; KHONG, K. W.; GOH, W. W.; CHONG, A. Y. L. (2014). Examining the antecedents of persuasive EWOM messages in social media. Online Information Review, v. 38, n. 6, p. 746-768.

WATHEN, C. N.; BURKELL, J. (2002) Believe it or not: Factors influencing credibility on the Web. Journal of the Association for Information Science and Technology, v. 53, n. 2, p. 134-144.

ZHANG, J. Q.; CRACIUN, G.; SHIN, D. (2010) When does electronic word-of-mouth matter? A study of consumer product reviews. Journal of Business Research, v. 63, n. 12, p. 1336-1341.

ZHU, F.; ZHANG, M. (2010) Impact of Online Consumer Reviews on Sales: The Moderating Role of Product and Consumer Characteristics. Journal of Marketing, v. 74, n. 2, p. 133-148. 